\title{
Does Geographical Proximity Affect Corporate Social Responsibility? Evidence from U.S. Market
}

\begin{abstract}
Ardisak Boeprasert
Correspondence: Ardisak Boeprasert, Graduate School of Business Administration, National Institute of Development Adminstration, Bangkok, 10240, Thailand. Tel: 662-727-3939. E-mail: ardisak_b@yahoo.com
\end{abstract}

Received: June 16, 2012

Accepted: July 5, 2012

Online Published: August 8, 2012

doi:10.5539/ibr.v5n9p138

URL: http://dx.doi.org/10.5539/ibr.v5n9p138

\begin{abstract}
Corporate Social Responsibility is considered as a key corporate agenda in recent years. This study examines the relation between geographical proximity to metropolitan areas and corporate social responsibility. Methodologically, sample firms are classified by their distance to top-metropolitan area of Census 2010. Corporate social responsibility follows scoring system, which has been developed by the notable KLD Research \& Analytics. Based on the samples from U.S. listed firms, the results support the main hypothesis that firm locating further from metropolitan areas tends to commit greater degree of social responsibility than those locating nearby top-metropolitan areas. Social responsible activities are exploited as a mean to alleviate information asymmetry and agency conflict rose from a distance. Besides, further investigation shows that the results above are potentially explained by some attributes of corporate social responsibility. These results are important to academic field because they show that the extent of any non-financial corporate activity, i.e. corporate social responsibility, can be explained by its geographical background.
\end{abstract}

Keywords: corporate social responsibility, geographical proximity, information asymmetry

\section{Introduction}

Social responsibility has emerged as a debating business issue, particularly how firms can obtain some benefit from this kind of activities. Henry Ford once quotes "A business that makes nothing but money is a poor kind of Business" (Wulfson, 2001), which shed light on something beyond economic, technical, or legal requirements. Specifically, the social responsibility concept expands corporate focus to societal matter. In spite of the inconclusive definition (Wood, 1991; Carroll, 1991), corporate social responsibility (CSR) consistently uses the social responsibility concept as a principle for every feature of organizational activities, while spreading this concept out to the stakeholders (Bringle \& Hatcher, 2002).

One of the pioneer publications on CSR was written by Howard R. Bowen in 1953, titled the "Social Responsibilities of the Businessman”. It highlighted a company's role beyond the financial benefits. Common definition of the social responsibility of businessmen was "it refers to the obligations of businessmen to pursue those policies to make those decisions or to follow those lines of relation which are desirable in terms of the objectives and values of our society" (Carroll, 1999).

Since then, academic study in CSR has grown substantially. It has been encouraging the importance of CSR in managerial practice worldwide to examine its effect and whether the firms are able to obtain some benefit from CSR practice. In addition, CSR is a critical part of corporate strategy considering its ability to create long-term competitive advantage (Gladwin et al., 1995).

Past literature on CSR has found a large number of its association with financial policies, financial performance, and other business performance (Cochran \& Wood, 1984; Galbreath, 2010; Orlitzky et al., 2003). However, it is a small number of studies tapping into its relation to the geographical background of the firms. Therefore, this study is desired to examine whether corporate location affects the CSR level of U.S. firms. The reason behind considering corporate location is motivated by three deliberations. First, corporate location has associated to corporate policies and decision-making processes (John, Knyazeva \& Knyazeva, 2010; Loughran, 2008); Second, it can influence corporate outcome (Porter, 2000); and last, most of its literature on some element of CSR is limited to its dispersion and multinational perspective (Brammer, Pavelin \& Porter, 2006; Maignan \& Ralston, 2002). Countries exhibit robust differences with respect to regulation, culture, and language, all of which make it difficult to isolate the impact of location on economic outcomes. Therefore, this study tries to 
probe into the difference of the societies occupying the same country, united under the same government, and usually speaking the same language.

This study is organized as follows: Section 2 covers the theoretical background and outlines hypothesis development. Section 3 explains the data and methodology. Section 4 highlights the results from multivariate analysis and Section 5 concludes.

\section{Theoretical Background and Hypothesis Development}

The line of CSR study has emerged when Dodd (1932) began arguing for and against the direct participation of the firm in societal development. Its early day divulges the interest in firms as entities with plentiful resources and the ability to leverage. However, their ability to manage assets properly is still questionable (Dodd, 1932; Levitt, 1958; Moskowitz, 1972). The early supporters view CSR as a potential business opportunity to be capitalized (Carroll, 1979; Davis, 1973) while, the naysayers argue on the loss of capitalism through such broad-based societal support (Friedman, 1970; Levitt, 1958). As an example, Milton Friedman (1970) highlighted on the doctrine of social responsibility and indicated that only individuals can have this responsibility. Social responsibility is then directed at the management executives, not the whole firms.

Operational definitions of CSR vary widely by author and time, with class four-facet model of Carrol (1979) as an example. He suggested that firms have four responsibilities to be a good corporate citizen: economic, legal, ethical, and Philanthropic. Nowadays, CSR is broadly defined as the duty of the organization to respect individual rights and promote human welfare in its operations (Manakkalathil \& Rudolf, 1995; Oppewal et al., 2006). It is the continuing commitment by business to behave ethically and contribute to economic development together with uplifting the quality of life of employees and their families as of the local community at large (WBCSD, 1999)

In many diverse perspectives, CSR has been considered as a mainstream of competitive advantages. CSR has shown explanatory power in business performance for example attractiveness to prospective employees (Backhaus et al., 2002), corporate reputation (Brammer \& Pavelin, 2006), and customer relation (Becker-Olsen et al., 2006). By interviewing stakeholders, Dentchev (2004) found great support to positive effect to relationship with employees, customers, government agents, and community.

Since the 1960s, substantial studies have addressed on the association between CSR and corporate financial performance (CFP). Their prime objective is to product support for expenses on CSR practices. However, these studies have hardly reached real consensus. A positive association has been documented in many studies (e.g. Cochran \& Wood, 1984; Moskowitz, 1972) while many scholars disputed these positive results (Friedman, 1970; Aupperle et al., 1985) and some shown empirical negative evidence (Abott \& Monsen, 1979; Alexander \& Buchholz, 1978). Besides, their irrelevance has been found since there are so many intervening variables between CSR and CFP.

Substantial studies in the finance and economics literature have outlined the effects of corporate geographical backgrounds on their outcomes and activities. This variation can be explained by the association between geographical proximity and the extent of information asymmetry. Coval and Moskowitz (1999) found geographical proximity preference in both mutual fund managers and individual investors. Specifically, those fund managers were found to invest in firms locating $19 \%$ closer to them than that of benchmarking portfolio. Besides, Individual investors showed even more bias toward local equities than those funds. Considering equity issuance, Loughran and Schultz (2005) found that stocks of urban firms are more liquid and draw higher attraction from institutional investors. Degryse and Ongena (2005) found that loan rate of firm decrease with distance to its lending bank while, increase with that of competing lenders. John, Knyazeva, and Knyazeva (2010) found that rural firms have to commit higher financial leverage or dividends payout to compensate for information asymmetry and limit managers from empire building behavior. Porter (2000) indicated the importance of corporate location as a critical part of corporate strategy. In general, a firm's competitive advantage is subject to its location selection considering operating costs and revenue. In sum, most of these studies try to investigate the impact of "proximity-to-urban area". Urban firms are superior to rural firms considering their ability to economize communication cost and alleviate information asymmetry.

As theorized by Jensen and Meckling (1976), information and incentive problems are the main cause of conflict between principals and agents. Typically, Managers have information advantage and have an incentive to maximize their own wealth at the expense of the investors (agency problem). This conflict has been alleviated by corporate governance (CG), which is defined as a system providing checks and balances to control opportunistic behavior of those managers. CG has been linked to CSR by some of its crucial attribute for example, employee involvement, employee commitment, employee education and training (Maignan et al., 1999). Lopatta, 
Buchholz, and Kaspereit (2012) examine the direct relation between CSR and information asymmetry. In the cross-sectional regression they found evidence that corporate social responsibility appear to reduce abnormal returns and therefore informational asymmetry. Specifically, Firms with high sustainability-ranking tend to have a higher level of voluntary disclosure, which increasing financial transparency and alleviating informational asymmetry.

From the evidence above, the ideas on information asymmetry can lead to the hypothesis on the relation between geographical closeness and CSR. CSR activities could promote transparency. The geographic proximity between the firm and its investors could alleviate these agency problems by facilitating better monitoring and relationship building. Therefore, firms locating in rural areas will commit a higher level of CSR in order to satisfy shareholders and alleviate agency problems.

\section{Methodology and Data}

\subsection{Methodology}

The main purpose of this study is to examine whether geographical proximity can affect levels of CSR and its attributes. Specifically, the study attempt to provide answers to following research questions:

Q1: Does geographical proximity to metropolitan areas affect the level of CSR?

Q2: Does geographical proximity to metropolitan areas affect value of its attributes?

To answer these questions, each sample firm must be classified as urban or rural firm. Considering the classification process, this study follows Loughran and Schultz (2005) and uses headquarter to represent its location. Corporate headquarters is the center of information exchange between the firm and its investors (Davis \& Henderson, 2008). Bower (1971) concluded that headquarters have to fulfil the regulatory requirement, manage governance functions, and undertaking the budgeting process. Paterson and Brock (2002) claim on low resistance when the decision is made by headquarter. Headquarter location of selected firms can be obtained from Compustat. A firm is defined as "urban firm" if headquarter locates within 100 miles from one of the ten largest metropolitan areas of the United States according to the 2010 census. A firm is considered as "rural firm" if headquarter locates within 100 miles from any of 51 metropolitan areas. Similar to Loughran (2008), the firm is defined as "small city firm" if it fails to meet those two criteria. Distance from headquarter to each metropolitan area is computed by simple spherical law of cosines formula.

$$
D_{a, b}=\operatorname{arcos}\left[\sin \left(\text { lat }_{a}\right) * \sin \left(\text { lat }_{b}\right)+\cos \left(\text { lat }_{a}\right) * \cos \left(\text { lat }_{b}\right) * \cos \left(\text { long }_{a}-\text { long }_{b}\right)\right] * R
$$

Where $\mathrm{R}$ is the radius of the earth (6,371 kilometers) and lat and long are latitudes and longitudes respectively.

As developed by the notable KLD Research \& Analytics, Inc, KLD score measure CSR based on seven related attributes regarding a set of questions on strength and concern. In particular, these seven attributes include environment, community, diversity, employee relation, product, corporate governance, and human rights. These attributes cover the different stakeholders' perspectives. Its coverage has kept enlarging since the inclusion of firms in the Russel 1000 Index, the Large Cap Index, the Russek 2000, and the Board Market Social Index during 2001-2005.

To figure out the aggregate KLD score, there are two computation techniques. Equal-weighted technique is to simply sum up the score from seven attributes. However, Akpinar et al. (2008) introduced "The stakeholder-weighted technique”, considering weight-adjusted score for the specific industry-year. Firms are classified on 9 industries comprising basic industries, capital goods, construction, consumer goods, energy, finance, transportation, utilities and others.

Multivariate regression is used to explore the association between geographical proximity and CSR. This regression is written as follows;

$$
\operatorname{CSR}_{i, t}=\alpha_{t}+\beta_{i} * \text { Control }_{i, t}+\lambda_{1} * \text { Urban firm }+\lambda_{2} * \text { Small city }+\gamma_{1} * I N D+\gamma_{2} * Y E A R+\varepsilon_{i, t}
$$

Where $\mathrm{CSR}_{\mathrm{i}, \mathrm{t}}$ denotes CSR variable, $\alpha_{\mathrm{t}}$ is the year fixed effect, IND are industry fixed effect, YEAR are year fixed effect, Control $\mathrm{i}_{\mathrm{i}, \mathrm{t}}$ are corporate-level control variables, "Urban firm" ,and "Small city" are dummy variables considering proximity to metropolitan areas, and $\varepsilon_{\mathrm{i}, \mathrm{t}}$ is an i.i.d error term.

Considering control variables, firm size is an important factor. Large firms are more likely to adopt the CSR program since their greater social impact. Risk is also taken into account since substantial studies found that a firm with proactive CSR program tends to anticipate and reduce potential sources of business risk, for example environmental damage, labor unrest, and potential governmental regulation (Orlitzky \& Benjamin, 2001). Debt-to-assets ratio has been found as a proxy for management risk tolerance (Choi et al., 2008). Firms with a greater degree of information disclosure on CSR have displayed greater sales growth according to Prado-Lorenzo et al. (2008). ROA is an indicator of the capital intensity of the firm, which depends upon the 
industry. It is widely used in the previous works (Aupperle et al., 1985; McWilliams \& Siegel, 2001). R\&D expenses are able to signal awareness on certain societal issue. McWilliams and Siegel (2001) asserted that the use of CSR resource may include $R \& D$ in order to strengthen competitive advantage.

In sum, control variables in this study include Size $=\log$ (total asset), Risk = Long-term debt-to-total asset ratio, $\Delta$ sales $_{\mathrm{t}}=\log ($ Sales in year $\mathrm{t} /$ Sales in year $\mathrm{t}-1), \Delta$ sales $_{\mathrm{t}-1}=\log ($ Sales in year $\mathrm{t}-1 /$ Sales in year $\mathrm{t}-2)$, ROA $=$ Net income/total assets, and $\mathrm{R} \& \mathrm{D}=\mathrm{R} \& \mathrm{D}$ expenditure/ total asset.

Besides, it is necessary to control for industry fixed effects since many industries tend to cluster around a geographical area. These firms obtain either cost and exogenous natural advantages or utilizing human capital according to positive externalities. This study follows the Waddock and Graves (1997) approach, which control by using 4-digit SIC.

\subsection{Data and Sample Selection}

The initial sample of this study consists of 17083 U.S. listed firm-year observations for the period 1995 to 2007. Firms with headquarter locate outside U.S. territory will be excluded. As to control past performance, it requires a firm either been established before 1993 or drop the $1^{\text {st }}$ two years out if that firm began its operation between the aforesaid sample periods. Eventually, the final sample is dropped to 10,794 firm-year observations with 2,203 unique firms. Corporate financial data and headquarter location are taken from Compustat's Global Industrial/Commerical database and I/B/E/S detail history files. As mentioned earlier, CSR is represented by a KLD score from KLD Research \& Analytics, Inc.

\section{Results}

\subsection{Descriptive Statistics}

From descriptive statistics in table 1, urban firms on average display slightly higher CSR level than rural firms. Specifically, the average KLD score of urban firms is equal to 0.261 while, rural firms have been scored with mean of 0.249 . However, this superiority can potentially be explained by the larger asset size. Urban firms commit a lower level of debt in comparison to the rural firms (0.197 vs. 0.185$)$. This result contradicts to the notion from John, Knyazeva, and Knyazeva (2010) that rural (or remote) firm will alleviate information asymmetry by committing more debt usage. In addition, the R\&D expense of urban firms is about twofold of rural firms.

Table 1. Descriptive Statistics for all of variables

\begin{tabular}{lcccc}
\hline & $\begin{array}{c}\text { Full Sample } \\
\text { Mean }\end{array}$ & $\begin{array}{c}\text { Urban Firms } \\
\text { Mean }\end{array}$ & $\begin{array}{c}\text { Small City Firms } \\
\text { Mean }\end{array}$ & $\begin{array}{c}\text { Rural Firms } \\
\text { Mean }\end{array}$ \\
\hline Panel A: CSR Score & & & & 0.249 \\
KLD score & 0.284 & 0.261 & 0.321 & 0.105 \\
Communication & 0.139 & 0.164 & 0.112 & -0.078 \\
Corporate governance & -0.321 & -0.370 & -0.306 & 0.329 \\
Diversity & 0.474 & 0.535 & 0.425 & -0.064 \\
Employee relation & -0.073 & -0.108 & -0.029 & -0.211 \\
Environment & -0.150 & -0.146 & -0.142 & -0.078 \\
Human rights & -0.076 & -0.086 & -0.063 & 0.245 \\
Product & 0.291 & 0.272 & 0.325 & 0.185 \\
Panel B: Control Variables & & & & 21.544 \\
Debt ratio & 0.191 & 0.197 & 0.185 & 0.048 \\
Log(Asset) & 21.752 & 21.857 & 21.658 & 0.110 \\
ROA & 0.043 & 0.043 & 0.041 & 0.115 \\
Sales growth & 0.106 & 0.105 & 0.106 & 0.014 \\
Sales growth (-1) & 0.116 & 0.114 & 0.118 & $\mathbf{4 2 9 1}$ \\
R\&D & 0.028 & 0.026 & 0.033 & $\mathbf{8 7 6}$ \\
Number of Sample & $\mathbf{1 0 7 3 9}$ & $\mathbf{5 5 7 2}$ & & . \\
\hline
\end{tabular}

Discription: This descriptive statistics are shown in the full sample and by geographical categories ("Urban”, "Small city” or "Rural”). A selected firm is classified as "Urban" if its headquarter locates within 100 miles from the center of any top-10 Metropolitan areas, while "Rural" means any firm, which does not locate within 100 miles from any of top-51 metropolitan areas. Otherwise it will be considered as "Small city". The dependent variable is equal-weighted KLD score, which is exploited to measure CSR. Log (asset) is logarithmic of asset to control for asset size. The debt ratio is long-term debt scaled by total assets. ROA is return on total assets. The sales growth is the growth of sales revenue in that year. The sales growth $(-1)$ is the growth of sales revenue on last year. R\&D is the corporate R\&D expense standardized by total assets. 
Considering each of seven attributes, urban firm show the better mean of score in communication, diversity, environment and product. For example, the mean score of communication for urban firms is 0.164 compared with 0.105 for the average of rural firms. Wide difference is found on diversity score between urban firms and rural firms (0.535 vs. 0.329). Nevertheless, rural firms hold the better score in CG and employee relation. Number of types of firms are just about the same (5 572 of urban firms vs. 4291 of rural firms). Thus, this evidence can clarify any concern on selection bias.

\subsection{Multivariate Analysis}

The multivariate regression is applied to both calculation techniques. The results from equal-weighted and stakeholder-weighted KLD score are shown in table 2 and 3 respectively. From table 2, urban firms tend to commit lower level of CSR than rural firms after controlling for financial-related variables, year fixed effects, and industry fixed effects correspondingly. Coefficient of "Urban firm" variable is negative and significant statistically (-0.238 with standard error of -2.55$)$.

Table 2. Multivariate Regression Analysis (Equal-weighted KLD Score)

\begin{tabular}{|c|c|c|c|c|}
\hline Variables & $\begin{array}{c}\text { Model1 } \\
\text { (OLS) }\end{array}$ & $\begin{array}{c}\text { Model2 } \\
\text { (OLS) }\end{array}$ & $\begin{array}{l}\text { Model3 } \\
\text { (OLS) }\end{array}$ & $\begin{array}{c}\text { Model4 } \\
\text { (OLS) }\end{array}$ \\
\hline Intercept & $\begin{array}{c}0.249 \\
(2.83)^{* * *}\end{array}$ & $\begin{array}{c}-7.093 \\
(-21.10)^{* * * *}\end{array}$ & $\begin{array}{l}-10.122 \\
(-14.14)^{* * * *}\end{array}$ & $\begin{array}{c}-9.456 \\
(-6.78)^{* * *}\end{array}$ \\
\hline \multicolumn{5}{|l|}{ Explanatory variables } \\
\hline Urban & $\begin{array}{l}0.013 \\
(0.13)\end{array}$ & $\begin{array}{l}-0.132 \\
(-1.44)\end{array}$ & $\begin{array}{c}-0.195 \\
(-2.06)^{* *}\end{array}$ & $\begin{array}{c}-0.238 \\
(-2.55)^{* *}\end{array}$ \\
\hline Small city & $\begin{array}{l}0.072 \\
(0.75)\end{array}$ & $\begin{array}{l}-0.057 \\
(-0.6)\end{array}$ & $\begin{array}{l}0.025 \\
(0.26)\end{array}$ & $\begin{array}{l}-0.017 \\
(-0.18)\end{array}$ \\
\hline \multicolumn{5}{|l|}{ Control variables } \\
\hline Debt ratio & & $\begin{array}{c}-1.511 \\
(-11.62)^{* * * *}\end{array}$ & $\begin{array}{c}-1.152 \\
(-7.99)^{* * *}\end{array}$ & $\begin{array}{c}-1.072 \\
(-7.52)^{* * *}\end{array}$ \\
\hline Log(Asset) & & $\begin{array}{c}0.348 \\
(23.17)^{* * * *}\end{array}$ & $\begin{array}{c}0.454 \\
(26.32)^{* * *}\end{array}$ & $\begin{array}{c}0.404 \\
(22.87)^{* * * *}\end{array}$ \\
\hline ROA & & $\begin{array}{c}1.356 \\
(6.4)^{* * * *}\end{array}$ & $\begin{array}{c}0.827 \\
(4.12)^{* * * *}\end{array}$ & $\begin{array}{c}0.900 \\
(4.53)^{* * * *}\end{array}$ \\
\hline Sales growth & & $\begin{array}{l}0.035 \\
(0.36)\end{array}$ & $\begin{array}{c}0.161 \\
(1.86)^{*}\end{array}$ & $\begin{array}{c}0.241 \\
(2.80)^{* * * *}\end{array}$ \\
\hline Sales growth $(-1)$ & & $\begin{array}{c}-0.212 \\
(-2.28)^{* * *}\end{array}$ & $\begin{array}{l}-0.088 \\
(-1.06)\end{array}$ & $\begin{array}{l}-0.044 \\
(-0.53)\end{array}$ \\
\hline R\&D & & $\begin{array}{c}5.227 \\
(11.93)^{* * * *}\end{array}$ & $\begin{array}{c}1.521 \\
(2.74)^{* * * *}\end{array}$ & $\begin{array}{c}1.565 \\
(2.86)^{* * * *}\end{array}$ \\
\hline Control industry effect & No & No & Yes & Yes \\
\hline Control year effect & No & No & No & Yes \\
\hline$\overline{\text { No. of Observation }}$ & 10794 & 10794 & 10794 & 10794 \\
\hline Adjusted R2 & 0.00 & 0.06 & 0.28 & 0.30 \\
\hline Overall F-stat & $\begin{array}{c}0.73 \\
0.483\end{array}$ & $\begin{array}{c}92.06 \\
0.000^{* * *}\end{array}$ & $\begin{array}{c}12.00 \\
0.000^{* * *}\end{array}$ & $\begin{array}{c}12.69 \\
0.000^{* * * *}\end{array}$ \\
\hline
\end{tabular}

Discription: The dependent variable is equal-weighted KLD score, which is exploited to measure CSR. "Urban" is a dummy variable equal to 1 if that firm's headquarter locates within 100 miles from center of any top-10 metropolitan areas and 0 for otherwise. "Small City" is a dummy variable equal to 1 if that firm's headquarter does not locate within 100 miles from center of any top-10 metropolitan areas but within that 100-mile radius of any of the remaining top metropolitan areas and 0 for otherwise. Log (asset) is logarithmic of asset to control for asset size. The debt ratio is long-term debt scaled by total assets. The return on asset is net income divided by total assets. The sales growth is the growth of sales revenue in that year. The sales growth $(-1)$ is the growth of sales revenue on last year. R\&D is the corporate R\&D expense standardized by total asset. ${ }^{*}$ Significant at $10 \%$ level, ${ }^{* *}$ Significant at $5 \%$ level, and ${ }^{* * *}$ Significant at $1 \%$ level.

Considering stakeholder-weight technique, this result from table 3 is consistent with that of equal-weighted one. Specifically, Coefficient of "Urban firm" variable is negative after the set of control variables is taken into account. However, this negative coefficient is significant $(-0.025$ with standard error of -1.98$)$ only after including simultaneous controls of industry and year fixed effects. These results support the main hypothesis that rural firms tend to commit higher lower of CSR than urban firms. It can be explained by the idea that rural firms try to alleviate investors' concern over information asymmetry. Apart from financial obligation, rural firms promote transparency and signal their commitment to the investors by using their social responsibility activities. 
Considering the control variables, estimated coefficients of asset size are unanimously positive and strongly significant. These coefficients reflect how KLD score changes if the asset size increases for $100 \%$. For example, fully-controlled model in table 2 show this coefficient equal to 0.404 so that KLD score will increase if a firm can double its asset size. Coefficients of long-term debt-to-total assets ratio is significantly negative (at 0.01 level). This result supports literature that a firm, which proactively involves CSR in managerial practice, has a higher propensity to anticipate and trim down the source of business risk. Thus, increasing level of debt will affect adversely on level of CSR. Sales growth of current year show significant positive effect after fully controlling those year and industry fixed effects. This is consistent with the evidence from Prado-Lorenzo et al. (2008) that a firm with greater information disclosure on CSR exhibits higher sales growth. Past sales growth displays negative effect to KLD score. Hypothetically, it can be explained by mean reversion of sales growth. However, five of those six values are not statistically significant. When a firm spends more on research and development, it will enhance knowledge and lead to differentiation and innovation. This firm can exploit differentiating strategy to create a socially responsible image. Consistent with this notion, R\&D expenses variable is strongly positive at 0.01 level in case of equal-weighted score while this positive effect on stakeholder-weighted score is not significant after controlling for industry and year-fixed effects.

Table 3. Multivariate Regression Analysis (Stakeholder-weighted KLD Score)

\begin{tabular}{|c|c|c|c|c|}
\hline Variables & $\begin{array}{c}\text { Model1 } \\
\text { (OLS) }\end{array}$ & $\begin{array}{c}\text { Model2 } \\
(\text { OLS) }\end{array}$ & $\begin{array}{c}\text { Model3 } \\
\text { (OLS) }\end{array}$ & $\begin{array}{c}\text { Model4 } \\
\text { (OLS) }\end{array}$ \\
\hline Intercept & $\begin{array}{l}-0.011 \\
(-0.87)\end{array}$ & $\begin{array}{c}-0.818 \\
(-16.41)^{* * *}\end{array}$ & $\begin{array}{c}-1.344 \\
(-13.50)^{* * *}\end{array}$ & $\begin{array}{c}-0.824 \\
(-8.49)^{* * *}\end{array}$ \\
\hline \multicolumn{5}{|l|}{ Explanatory variables } \\
\hline Urban & $\begin{array}{l}0.015 \\
(1.10)\end{array}$ & $\begin{array}{c}-0.0005 \\
(0.01)\end{array}$ & $\begin{array}{l}-0.013 \\
(-1.00)\end{array}$ & $\begin{array}{c}-0.025 \\
(-1.98)^{* *}\end{array}$ \\
\hline Small city & $\begin{array}{l}0.006 \\
(0.01)\end{array}$ & $\begin{array}{l}-0.007 \\
(-0.51)\end{array}$ & $\begin{array}{l}0.008 \\
(0.64)\end{array}$ & $\begin{array}{l}-0.004 \\
(-0.29)\end{array}$ \\
\hline \multicolumn{5}{|l|}{ Control variables } \\
\hline Debt ratio & & $\begin{array}{c}-0.241 \\
(-12.49)^{* * *}\end{array}$ & $\begin{array}{c}-0.115 \\
(-5.73)^{* * *}\end{array}$ & $\begin{array}{c}-0.092 \\
(-4.86)^{* * *}\end{array}$ \\
\hline Log(Asset) & & $\begin{array}{c}0.039 \\
(17.49)^{* * * *}\end{array}$ & $\begin{array}{c}0.055 \\
(23.00)^{* * * *}\end{array}$ & $\begin{array}{c}0.040 \\
(17.02)^{* * * *}\end{array}$ \\
\hline ROA & & $\begin{array}{c}0.108 \\
(3.43)^{* * * *}\end{array}$ & $\begin{array}{c}0.071 \\
(2.56)^{* * *}\end{array}$ & $\begin{array}{c}0.094 \\
(3.55)^{* * * *}\end{array}$ \\
\hline Sales growth & & $\begin{array}{l}0.008 \\
(0.58)\end{array}$ & $\begin{array}{l}0.020 \\
(1.64)\end{array}$ & $\begin{array}{c}0.038 \\
(3.35)^{* * * *}\end{array}$ \\
\hline Sales growth $(-1)$ & & $\begin{array}{l}-0.015 \\
(-1.07)\end{array}$ & $\begin{array}{l}-0.002 \\
(-0.13)\end{array}$ & $\begin{array}{l}-0.044 \\
(-0.53)\end{array}$ \\
\hline $\mathrm{R} \& \mathrm{D}$ & & $\begin{array}{c}0.511 \\
(7.87)^{* * * *}\end{array}$ & $\begin{array}{l}0.123 \\
(1.60)\end{array}$ & $\begin{array}{l}0.146 \\
(2.00)\end{array}$ \\
\hline Control industry effect & No & No & Yes & Yes \\
\hline$\underline{\text { Control yearly effect }}$ & No & No & No & Yes \\
\hline No. of Observation & 10794 & 10794 & 10794 & 10794 \\
\hline Adjusted R2 & 0.001 & 0.04 & 0.35 & 0.42 \\
\hline Overall F-stat & $\begin{array}{c}1.04 \\
0.354\end{array}$ & $\begin{array}{c}59.60 \\
0.000^{* * * *}\end{array}$ & $\begin{array}{c}16.33 \\
0.000^{* * *}\end{array}$ & $\begin{array}{c}20.71 \\
0.000^{* * *}\end{array}$ \\
\hline
\end{tabular}

Discription: The dependent variable is stakeholder-weighted KLD score, which is exploited to measure CSR. "Urban" is a dummy variable equal to 1 if that firm's headquarter locates within 100 miles from center of any top-10 metropolitan areas and 0 for otherwise. "Small City" is a dummy variable equal to 1 if that firm's headquarter does not locate within 100 miles from center of any top-10 metropolitan areas but within that 100-mile radius of any of the remaining top metropolitan areas and 0 for otherwise. Log (asset) is logarithmic of asset to control for asset size. The debt ratio is long-term debt scaled by total assets. The return on asset is net income divided by total assets. The sales growth is the growth of sales revenue in that year. The sales growth (-1) is the growth of sales revenue on last year. R\&D is the corporate R\&D expense standardized by total asset. ${ }^{*}$ Significant at $10 \%$ level, ${ }^{* *}$ Significant at $5 \%$ level, and ${ }^{* * *}$ Significant at $1 \%$ level.

These results are robust to variation of cutoff radius. Rural firms still display a superior level of CSR than urban firms when this study varies cutoff point from 100 miles to 50 and 75 miles respectively. However, this result is not tabulated in this study. 


\subsection{Multivariate Analysis on Seven Attributes}

In this sub-section, equation 2 is applied to seven attribute of CSR, which are the environment, community, diversity, employee relation, product, corporate governance, and human rights. The aggregated score of each attribute is computed on questions regarding to strength and concern. There are substantial studies about association between these attributes and location. For example, Rabainski (2007) indicated that a firm's expansion and decision on location are associated with cost-benefit analysis. Based on corporate quality of life (QOL) study, employee quality of life is strongly related to the economic study of relocation decision. The appropriate location will be able to minimize key employee turnover at the new site and trimming down training cost for new employees. Based on data from the U.S. Census Bureau, the employment-to-population ratio has varied across MSA. For example, this ratio in 2010 is the highest at 74.8\% in Minneapolis-St. Paul-Bloomington (MN-WI) while the lowest one is $59.4 \%$ in Riverside-San Bernardino-Ontario, CA. Letchumanon and Kodama (2000) showed the international evidence that a polluting firm considers entering to a country whose pollution controlling system is lax in comparison to that of its home country. Dam et al. (2007) asserted that firms with high CG have incentives to locate their subsidiaries in the countries with more relaxing governance codes.

Table 4 shows multivariate regression on each CSR attribute with the same explanatory and control variables as aggregated KLD score. The results show that "Urban Firm" variable is significant to explain three of these seven attributes. On average, urban firms tend to have favorable communication in comparison to rural firms. Specifically, urban firms have about 0.06 higher scores of communication than corresponding rural firms. This result is intuitive as metropolitan areas have better access to media, or any of the communication channel comparing with rural areas.

Table 4. Multivariate Regression Analysis (seven attributes of CSR)

\begin{tabular}{|c|c|c|c|c|c|c|c|}
\hline Dependent Variables & $\begin{array}{l}\text { COM } \\
\text { (OLS) }\end{array}$ & $\begin{array}{c}\text { CG } \\
\text { (OLS) }\end{array}$ & $\begin{array}{c}\text { DIV } \\
\text { (OLS) }\end{array}$ & $\begin{array}{l}\text { EMP } \\
\text { (OLS) }\end{array}$ & $\begin{array}{l}\text { ENV } \\
\text { (OLS) }\end{array}$ & $\begin{array}{l}\text { HMR } \\
\text { (OLS) }\end{array}$ & $\begin{array}{c}\text { PRO } \\
\text { (OLS) }\end{array}$ \\
\hline Intercept & $\begin{array}{c}-2.154 \\
(-11.30)^{* * *}\end{array}$ & $\begin{array}{c}4.346 \\
(20.52)^{* * * *}\end{array}$ & $\begin{array}{c}-8.650 \\
(-24.73)^{* * *}\end{array}$ & $\begin{array}{c}-0.982 \\
(-3.61)^{* * * *}\end{array}$ & $\begin{array}{c}0.472 \\
(2.37)^{* * *}\end{array}$ & $\begin{array}{c}0.497 \\
(5.94)^{* * * *}\end{array}$ & $\begin{array}{c}-1.828 \\
(-1.39)^{* * *}\end{array}$ \\
\hline \multicolumn{8}{|l|}{ Explanatory variables } \\
\hline Urban & $\begin{array}{c}0.060 \\
(2.43)^{* * *}\end{array}$ & $\begin{array}{c}-0.145 \\
(-5.33)^{* * * *}\end{array}$ & $\begin{array}{l}-0.043 \\
(-0.96)\end{array}$ & $\begin{array}{c}-0.098 \\
(-2.81)^{* * * *}\end{array}$ & $\begin{array}{l}-0.007 \\
(-0.27)\end{array}$ & $\begin{array}{l}0.014 \\
(1.28)\end{array}$ & $\begin{array}{l}-0.018 \\
(-0.86)\end{array}$ \\
\hline Small city & $\begin{array}{l}0.025 \\
(1.00)\end{array}$ & $\begin{array}{c}-0.010 \\
(-3.65)^{* * *}\end{array}$ & $\begin{array}{l}0.015 \\
(0.34)\end{array}$ & $\begin{array}{l}-0.015 \\
(-0.43)\end{array}$ & $\begin{array}{l}0.004 \\
(0.15)\end{array}$ & $\begin{array}{l}0.015 \\
(1.38)\end{array}$ & $\begin{array}{l}0.039 \\
(1.89)^{*}\end{array}$ \\
\hline \multicolumn{8}{|l|}{ Control variables } \\
\hline Debt ratio & $\begin{array}{c}-0.158 \\
(-4.22)^{* * *}\end{array}$ & $\begin{array}{c}-0.114 \\
(-2.74)^{* * *}\end{array}$ & $\begin{array}{c}-0.365 \\
(-5.32)^{* * *}\end{array}$ & $\begin{array}{c}-0.302 \\
(-5.66)^{* * * *}\end{array}$ & $\begin{array}{l}0.0001 \\
(0.00)\end{array}$ & $\begin{array}{c}0.043 \\
(2.63)^{* *}\end{array}$ & $\begin{array}{c}-0.177 \\
(-5.62)^{* * * *}\end{array}$ \\
\hline Log(Asset) & $\begin{array}{c}0.097 \\
(20.85)^{* * * *}\end{array}$ & $\begin{array}{c}-0.200 \\
(-39.03)^{* * * *}\end{array}$ & $\begin{array}{c}0.419 \\
(49.26)^{* * * *}\end{array}$ & $\begin{array}{c}0.075 \\
(11.33)^{* * * *}\end{array}$ & $\begin{array}{c}-0.056 \\
(-11.64)^{* * * *}\end{array}$ & $\begin{array}{c}-0.050 \\
(-24.44)^{* * * *}\end{array}$ & $\begin{array}{c}0.121 \\
(-30.93)^{* * * *}\end{array}$ \\
\hline ROA & $\begin{array}{c}0.107 \\
(2.04)^{* *}\end{array}$ & $\begin{array}{l}0.064 \\
(1.10)\end{array}$ & $\begin{array}{l}0.006 \\
(0.06)\end{array}$ & $\begin{array}{c}0.517 \\
(6.95)^{* * *}\end{array}$ & $\begin{array}{l}0.083 \\
(1.53)\end{array}$ & $\begin{array}{l}0.031 \\
(1.35)\end{array}$ & $\begin{array}{c}0.092 \\
(2.09)^{* * *}\end{array}$ \\
\hline Sales growth & $\begin{array}{c}0.047 \\
(2.06)^{* * *}\end{array}$ & $\begin{array}{c}0.080 \\
(3.18)^{* * * *}\end{array}$ & $\begin{array}{l}-0.016 \\
(-0.39)\end{array}$ & $\begin{array}{c}0.083 \\
(2.59)^{* * * *}\end{array}$ & $\begin{array}{l}0.034 \\
(1.43)\end{array}$ & $\begin{array}{l}0.006 \\
(0.66)\end{array}$ & $\begin{array}{l}0.007 \\
(0.36)\end{array}$ \\
\hline Sales growth (-1) & $\begin{array}{l}0.010 \\
(0.48)\end{array}$ & $\begin{array}{l}0.012 \\
(0.49)\end{array}$ & $\begin{array}{c}-0.119 \\
(-2.98)^{* * *}\end{array}$ & $\begin{array}{l}0.050 \\
(1.61)\end{array}$ & $\begin{array}{l}0.021 \\
(0.94)\end{array}$ & $\begin{array}{l}0.013 \\
(1.39)\end{array}$ & $\begin{array}{l}-0.032 \\
(-1.73)^{*}\end{array}$ \\
\hline $\mathrm{R} \& \mathrm{D}$ & $\begin{array}{c}0.387 \\
(2.69)^{* * * *}\end{array}$ & $\begin{array}{c}-0.673 \\
(-4.21)^{* * * *}\end{array}$ & $\begin{array}{c}1.127 \\
(4.27)^{* * * *}\end{array}$ & $\begin{array}{c}0.606 \\
(2.96)^{* * * *}\end{array}$ & $\begin{array}{l}-0.258 \\
(-1.72)^{*}\end{array}$ & $\begin{array}{c}-0.243 \\
(-3.85)^{* * * *}\end{array}$ & $\begin{array}{c}0.620 \\
(5.12)^{* * * *}\end{array}$ \\
\hline Industry effect & Yes & Yes & Yes & Yes & Yes & Yes & Yes \\
\hline$\underline{\text { Year effect }}$ & Yes & Yes & Yes & Yes & Yes & Yes & Yes \\
\hline Observation & 10794 & 10794 & 10794 & 10794 & 10794 & 10794 & 10794 \\
\hline Adjusted $\mathrm{R}^{2}$ & 0.24 & 0.27 & 0.39 & 0.23 & 0.42 & 0.29 & 0.27 \\
\hline Overall F-stat & $\begin{array}{c}9.60 \\
0.000^{* * *}\end{array}$ & $\begin{array}{c}11.31 \\
0.000^{* * *}\end{array}$ & $\begin{array}{c}18.34 \\
0.000^{* * *}\end{array}$ & $\begin{array}{c}9.33 \\
0.000^{* * *}\end{array}$ & $\begin{array}{c}21.78 \\
0.000^{* * *}\end{array}$ & $\begin{array}{c}12.53 \\
0.000^{* * *}\end{array}$ & $\begin{array}{c}11.26 \\
0.000^{* * *}\end{array}$ \\
\hline
\end{tabular}

Discription: COM = Equal-weighted score for community category in KLD index, CG = Equal-weighted score for corporate governance category in KLD index, DIV = Equal-weighted score for diversity category in KLD index, EMP = Equal-weighted score for employee relation category in KLD index, ENV = Equal-weighted score for environment category in KLD index, HMR = Equal-weighted score for human rights category in KLD index, PRO = Equal-weighted score for product category in KLD index, Debt ratio = Long-term debt/total asset, $\log ($ asset $)=$ logarithmic scale of total asset, ROA = return on assets, sales growth = revenue growth in this year, Sales growth $(-1)=$ revenue growth in last year, R\&D = R\&D expenses standardized by total asset. ${ }^{*}$ Significant at $10 \%$ level, ${ }^{* *}$ Significant at $5 \%$ level, and ${ }^{* * * *}$ Significant at $1 \%$ level. 
However, this superiority is overwhelmed by corporate governance and employee relation of rural firms. A rural firm tends to commit CG score at 0.145 greater than that of the corresponding urban form. Besides, rural firm seems to have better relationships with employee in comparison to matching urban firm. These results show that rural firms tend to use CG mechanism to alleviate information asymmetry. Hart (1995) defined CG as a system that provides checks and balances to control managerial behavior and thus tries to mitigate that managers pursue their own interests at the expense of shareholders. Better employee relation can be implied from the idea of Rabianski (2007) regarding corporate quality of life (QOL). Since rural firms can take advantage of cheaper administrative cost, they have greater remaining budget to fulfil their employees need. Beside, rural area is inferior to urban area in term of accessibility to the pool of talents and workforce. For this reason, rural firms will pay more attention to the relationship with employees in order to minimize turnover and cost related to training new employees. There is strong evidence to support the view that firm locating further from metropolitan areas tend to commit higher level of CSR activities.

\section{Conclusions and Remarks}

This study is the study of the relation between corporate geographical proximity to metropolitan areas and CSR of U.S. listed firms and covers the period 1995 to 2007. Headquarter location is exploited to represent firm considering its versatility and ability to control information flow. CSR measure is based on a scoring system developed by KLD Research \& Analytics, Inc. The main results of this study can be summarized as follows. First, examination of CSR and corporate location provides some interesting findings. There is strong evidence supporting that view that geographical proximity to metropolitan area can affect negatively to the CSR level of that firm. It is robust to calculation technique of CSR score and cutoff distance of urban firm. This evidence supports main hypothesis that rural firms tend to commit greater level of CSR than urban firms as to alleviate possible agency conflict arisen from information asymmetry.

Second, examination of seven attributes and corporate location provide strong evidence that some attributes can explain the superiority of rural firms. In spite of inferior communication, rural firms tend to commit greater level of CG than urban firms as a mean to provide checks and balances to control opportunistic behaviors of managers. The results also point out that rural firms tend to treat employees more appropriate than corresponding urban one considering their limitation to access pool of talents and workforce.

The superiority of rural firms is consistent with Urcan (2007), who documents that rural provide better quality of corporate disclosure. However, that corporate disclosure is represented by the likelihood of voluntary management earnings forecasts.

Lastly, this study contributes to future research topic in many dimensions. Corporate geographic context can be extended to dispersion of activities rather than limited to corporate headquarter. Different measure of geographical proximity (i.e. whether the firm locates in the top metropolitan areas, etc.) can be applied in this branch of study. In addition, scholars can examine relation between CSR and other non-financial activities (i.e. corporate governance, etc.).

\section{Acknowledgements}

I would like to express my gratitude to Dr. Pornsit Jiraporn and Dr. Viput Ongsakul for thier valuable advices.

\section{References}

Abbot, W., \& Monsen, R. (1979). On the measurement of corporate social responsibility: self-reported disclosure as a measure of corporate social involvement. Academy of Management Journal, 22, 501-15. http://dx.doi.org/10.2307/255740

Akpinar, A., Jiang, Y., Gomez-Mejia, L. R., Berrone, P., \& Walls, J. L. (2008). Strategic use of CSR as a signal for good management. IE Business School Working Paper.

Alexander, G. J., \& Buchholz, R. A. (1978). Corporate social responsibility and stock market performance. Academic of Management Journal, 21, 179-486. http://dx.doi.org/10.2307/255728

Aupperle, K. E., Carroll, A. B., \& Hatfield, J. D. (1985). An empirical examination of the relationship between corporate social responsibility and profitability. Academy of Management Journal, 28, 446-463. http://dx.doi.org/10.2307/256210

Backhaus, K. B., Stone, B. A., \& Heiner, K. (2002). Exploring the relationship between corporate social performance and employer attractiveness. Business and Society, 41(3), 292-318. http://dx.doi.org/10.1177/0007650302041003003 
Becker-Olson, K. L., Cudmore, A., \& Hill, R. P. (2006). The impact of perceived corporate social responsibility on consumer behavior. Journal of Business Research, 59, 46-53. http://dx.doi.org/10.1016/j.jbusres.2005.01.001

Brammer, S. J., \& Pavelin, S. (2006). Corporate reputation and social performance: The importance of fit. Journal of Management Studies, 43(3), 435-455. http://dx.doi.org/10.1111/j.1467-6486.2006.00597.x

Brammer, S. J., Pavelin, S., \& Porter, L. A. (2006). Corporate social performance and geographical

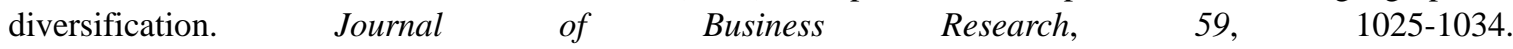
http://dx.doi.org/10.1016/j.jbusres.2006.04.001

Bringle, R. G., \& Hatcher, J. A. (2002). Campus-community partnerships: The terms of engagement. Journal of Social Issues, 58, 503-516. http://dx.doi.org/10.1111/1540-4560.00273

Carroll, A. B. (1979). A three-dimensional conceptual model of corporate performance. Academy of Management Review, 4(4), 497-505. http://dx.doi.org/10.5465/AMR.1979.4498296

Carroll, A. B. (1991). The pyramid of corporate social responsibility: Toward the moral management of $\begin{array}{llll}\text { organizational } \quad \text { stakeholders. } & \text { Business }\end{array}$ http://dx.doi.org/10.1016/0007-6813(91)90005-G

Carroll, A. B. (1999). Corporate social responsibility: Evolution of a definitional construct. Business and Society, 38(3), 268-295. http://dx.doi.org/10.1177/000765039903800303

Choi, J. S., Kwak, Y. M., \& Choe, C. W. (2010). Corporate Social Responsibility and Corporate Financial Performance: Evidence from Korea. Australian Journal of Management, 35(3), 291-311. http://dx.doi.org/10.1177/0312896210384681

Cochran, P. L., \& Wood, R. A. (1984). Corporate social responsibility and financial performance. Academy of Management Journal, 27(1), 42-56. http://dx.doi.org/10.2307/255956

Coval, J. D., \& Moskowitz, T. J. (1999). Home bias at home: Local equity preference in domestic portfolios. Journal of Finance, 54(6), 2045-2073. http://dx.doi.org/10.1111/0022-1082.00181

Dam, L., Scholtens, L. J. R., \& Sterken, E. (2007). Corporate governance and international location decisions of multinational enterprises. Corporate Governance: An International Review, 15, 1329-1346. http://dx.doi.org/10.1111/j.1467-8683.2007.00649.x

Davis, J. C., \& Henderson, J. V. (2008). The agglomeration of headquarters. Regional Science and Urban Economics, 38(5), 445-460. http://dx.doi.org/10.1016/j.regsciurbeco.2008.05.002

Davis, K. (1973). The case for and against business assumption of social responsibilities. Academy of Management Journal, 16(2), 312-322. http://dx.doi.org/10.2307/255331

Dentchev, N. A. (2004). Corporate social performance as a business strategy. Journal of Business Ethics, 55(4), 397-412. http://dx.doi.org/10.1007/s10551-004-1348-5

Dodd, E. M., Jr. (1932). For whom are corporate managers trustees?. Harvard Law Review, 45(7), 1145-1163. http://dx.doi.org/10.2307/1331697

Friedman, Milton. (1970, September 13). The Social Responsibility of Business Is to Increase Its Profits. The New York Times Magazine.

Galbreath, J. (2010). How does corporate social responsibility benefit firms? Evidence from Australia. European Business Review, 22(4), 411-431. http://dx.doi.org/10.1108/09555341011056186

Gladwin, T. N., Kennelly, J. J., \& Krause, T. S. (1995). Shifting Paradigms for Sustainable Development Implications for Management Theory and Research. Academy of Management Review, 20(4), 874-907. http://dx.doi.org/10.2307/258959

Hart, O. (1995). Corporate Governance: Some Theory and Implications. The Economic Journal, 105, 678-689. http://dx.doi.org/10.2307/2235027

Jensen, M. C., \& Meckling, W. H. (1976). Theory of the Firm: Managerial Behavior, Agency Costs and Ownership Structure. Journal of Financial Economics, 3(4), 305-360. http://dx.doi.org/10.1016/0304-405X(76)90026-X

John, K., Knyazeva, A., \& Knyazeva, D. (2010). Do shareholders care about geography?. Journal of Financial Economics. 
Letchumanan, R. L., \& Kodama, F. (2000). Reconciling the conflict between the "pollution haven" hypothesis and an emerging trajectory of international technology transfer. Research Policy, 29(1), 59-79. http://dx.doi.org/10.1016/S0048-7333(99)00033-5

Levitt, T. (1958). The dangers of social responsibility. Harvard Business Review, 36, 41-50.

Lopatta, K., Buchholz, F., \& Kaspereit, T. (2012, January 30). Asymmetric Information and Corporate Social Responsibility. Retrieved from http://ssrn.com/abstract=1995534 or http://dx.doi.org/10.2139/ssrn.1995534

Loughran, T. (2008). The Impact of Firm Location on Equity Issuance. Financial Management, 37, 1-21. http://dx.doi.org/10.1111/j.1755-053X.2008.00004.x

Loughran, T., \& Schultz, P. (2005). Liquidity: urban versus rural firms. Journal of Financial Economics, 78, 341-374. http://dx.doi.org/10.1016/j.jfineco.2004.10.008

Maignan, I., \& Ralston, D. A. (2002). Corporate social responsibility in Europe and the U.S.: Insights from businesses' self-presentations. Journal of International Business Studies, 33(3), 497-514. http://dx.doi.org/10.1057/palgrave.jibs.8491028

Maignan, I., Ferrell, O. C., \& Hult, G. T. M. (1999). Corporate citizenship: cultural antecedents and business benefits. Journal of the Academy of Marketing Science, 27(4), 455-469. http://dx.doi.org/10.1177/0092070399274005

Manakkalathil, J., \& Rudolf, E. (1005). Corporate social responsibility in a globalizing market. SAM Advanced Management Journal, 47, 29-32.

McWilliams, A. \& Siegel, D. (2001). Corporate social responsibility: A theory of the firm perspective. Academy of Management Review, 26(1), 117-127. http://dx.doi.org/10.5465/AMR.2001.4011987

Moskowitz, M. R. (1972). Choosing socially responsible stocks. Business and Society Review, 1, 1-7.

Oppewal, H., Alexander, A., \& Sullivan, P. (2006). Consumer perceptions of corporate social responsibility in town shopping centres and their influence on shopping evaluations. Journal of Retailing and Consumer Services, 13, 261-274. http://dx.doi.org/10.1016/j.jretconser.2005.08.015

Orlitzky, M., \& Benjamin, J. D. (2001). Corporate social performance and firm risk: A meta-analytic review. Business \& Society, 40(4), 369-396. http://dx.doi.org/10.1177/000765030104000402

Orlitzky, M., Schmidt, F. L., \& Rynes, S. L. (2003). Corporate social and financial performance: A meta-analysis. Organization Studies, 24, 403-441. http://dx.doi.org/10.1177/0170840603024003910

Paterson, S. L., \& Brock, D. M. (2002). The development of subsidiary management research: review and theoretical analysis. International Business Review, 11(2), 139-163. http://dx.doi.org/10.1016/S0969-5931(01)00053-1

Porter, M. E. (2000). Location, Competition and Economic Development: Local Clusters in a Global Economy. Economic Development Quarterly, 14(1), 15-34. http://dx.doi.org/10.1177/089124240001400105

Rabianski, J. S. (2007). Employee quality of life in corporate location decisions. Journal of Corporate Real Estate, 9(1), 50-64. http://dx.doi.org/10.1108/14630010710742482

Urcan, O. (2007). Geographical Location and Corporate Disclosures. Retrieved from http://ssrn.com/abstract=930433 or http://dx.doi.org/10.2139/ssrn.930433.

Waddock, S. A., \& Graves, S. B. (1997). The corporate social performance-financial performance link. Strategic $\begin{array}{lll}\text { Management } \quad \text { Journal, 303-319. } & \text { 18(4), }\end{array}$ http://dx.doi.org/10.1002/(SICI)1097-0266(199704)18:4<303::AID-SMJ869>3.0.CO;2-G

WBCSD. (1999). Corporate Social Responsibility. World Business Council for Sustainable Development.

Wood, D. J. (1991). Corporate social performance revisited. Academy of Management Review, 16(4), 691-718. http://dx.doi.org/10.5465/AMR.1991.4279616

Wulfson, M. (2001). The ethics of corporate social responsibility and philanthropic ventures. Journal of Business Ethics, 29, 135-145. http://dx.doi.org/10.1023/A:1006459329221 